\title{
Current models and practices of economic and environmental evaluation for sustainable network-level pavement management
}

\author{
Modelos y prácticas actuales en la evaluación económica y ambiental para la gestión sostenible de \\ redes de pavimentos
}

Cristina Torres-Machi (Main Author)

Universitat Politècnica de València,

School of Civil Engineering, Spain.

Pontificia Universidad Católica de Chile, Facultad de Ingeniería, Departamento de Ingeniería y Gestión de la Construcción, Chile. critorma@upv.es

Fono y fax: +34963879562; +34963877569

Camino de Vera sn, 46022 Valencia, España

\section{Alondra Chamorro}

National Research Center for Integrated Natural Disaster Management, Pontificia Universidad Católica de Chile.

Pontificia Universidad Católica de Chile, Facultad de Ingeniería, Departamento de Ingeniería y Gestión de la Construcción, Chile. achamorro@ing.puc.cl

\section{Resumen}

Las infraestructuras de transporte terrestre y particularmente la infraestructura vial son fundamentales en el desarrollo económico y social. El nivel de calidad percibido por el usuario viene determinado, principalmente, por el pavimento. A nivel mundial se invierte anualmente más de 400 mil millones de dólares en la construcción y el mantenimiento de pavimentos; tareas que aumentan en un $10 \%$ el impacto ambiental generado por la circulación de los vehículos. Surge así la necesidad de incorporar un enfoque sostenible en la evaluación de alternativas de conservación que considere aspectos técnicos, económicos, medioambientales, políticos e institucionales de forma integrada y armónica a lo largo de su ciclo de vida. La presente investigación tiene por objeto estudiar los modelos y prácticas en la evaluación económica y ambiental de pavimentos para analizar las ventajas y las limitaciones de la práctica actual e identificar oportunidades para mejorar su gestión sostenible. Una de las principales limitaciones identificadas es la escasez de modelos que consideren de forma integrada los aspectos económicos y ambientales. Se detecta la necesidad de modelos que consideren el efecto sobre los usuarios en zonas de trabajo así como el uso de nuevas tecnologías y materiales reciclados más respetuosos con el medio ambiente.

Palabras Clave: Evaluación del ciclo de vida, administración de activos, pavimentos, sustentabilidad.

\section{Introduction}

Transportation infrastructures are an important part of a country's assets; in addition, they are a key factor to achieve economic development, productivity improvement and social wellbeing (Uddin et al., 2013). Recent reports highlight its economic relevance; thus, more than 400 billion dollars are invested every year in the world in pavement construction and maintenance (IRF, 2010). From the environmental point of view, in the last years there has been an increased effort for the reduction and reuse of residues generated by the construction industry (Aldana \& Serpell, 2012). As for road infrastructures,
Víctor Yepes (Contact Author)

Universitat Politècnica de València,

School of Civil Engineering, Spain.

Universitat Politècnica de València, Departamento de Ingeniería de la Construcción, ICITECH, España.

vyepesp@upv.es

Eugenio Pellicer

Universitat Politècnica de València,

School of Civil Engineering, Spain.

pellicer@upv.es

\section{Manuscript Code: 0253}

Date of reception/acceptation: 01jan2014/01aug2014

\begin{abstract}
Ground transportation infrastructures, particularly road infrastructure, are essential for economic and social development. The quality level that the user perceives is mainly determined by the pavement condition. More than 400 billion dollars are invested globally each year in pavement construction and maintenance; these tasks increase by $10 \%$ the environmental impact generated by vehicle operation. Therefore, a sustainable approach should be incorporated in the assessment of preservation alternatives that consider technical, economic, environmental, political and institutional aspects in an integrated manner over their life-cycle. The purpose of the present research is to examine the models and practices for the economic and environmental evaluation of pavement assets, in order to analyze the advantages and limitations of the current state of the practice and identify the opportunities to improve their sustainable management. One of the main limitations identified is the lack of models that consider the economic and environmental aspects integrally. A need for models which consider the impact on users in work zones, as well as the use of new technologies and recycled materials that are more respectful of the environment, has been detected.
\end{abstract}

Keywords: Life-cycle assessment (LCA), asset management, pavement, sustainability.

the biggest efforts have been focused on reducing vehicle emissions, at the expense of the impact generated in the stages of construction, use and maintenance. According to some studies, this impact increases by $10 \%$ the impact generated by vehicle operation (Chester \& Horvath, 2009). This situation leads, inexorably, to a sustainable management of pavements, which deals with technical, economic, environmental, political and institutional criteria over their life-cycle. This view goes beyond the actions' immediate effect on these infrastructures (Chamorro, 2012; Chamorro \& Tighe, 2009; SADC, 2003). 
Pavement Management Systems (PMS) were introduced in the $20^{\text {th }}$ century during the sixties, in order to facilitate the preservation of pavement infrastructures. These systems transform the available data into useful information to help with the decision-making process in a structured way. The PMS can act at three different levels: (1) project-level management, where technical decisions are made concerning the design, construction and preservation of a specific pavement; (2) network-level management, which analyses a group of pavements in order to rank and schedule the works for their preservation under budget constraints; and (3) strategic-level management, which establishes general management objectives, preservation policies and the available resources. The management level has an impact on the time horizon of the analysis, the space coverage, and the detail of the data needed for the decision-making process (Solminihac, 2001; Uddin et al., 2013).

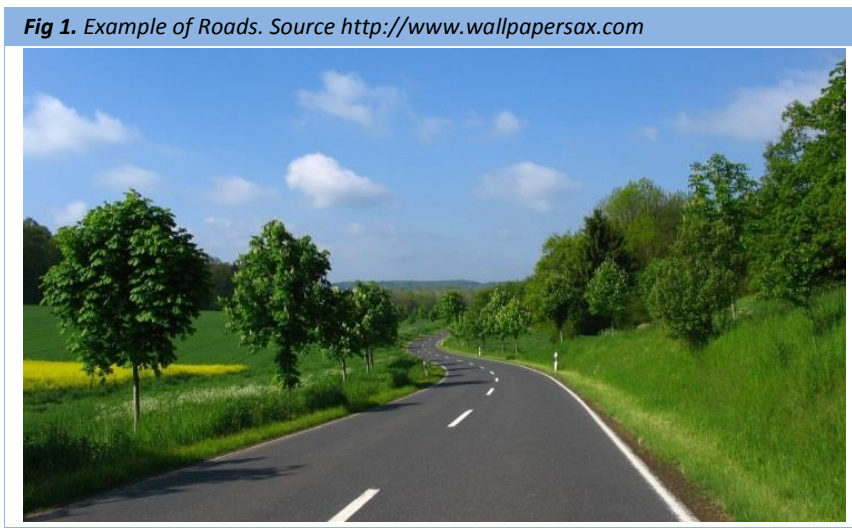

Objective, Scope and Method of the Study

The aim of this paper is to review the existing analyses, indicators and models for the economic and environmental evaluation applied to pavement management; present the advantages and limitations of the current state of the practice and identify opportunities to improve its sustainable management. The scope of the study is limited to a networklevel management, which evaluates first a set of alternatives and then optimizes and prioritizes available resources. The study is focused on the economic and environmental evaluation for the sustainable management of pavement infrastructure networks. Meanwhile, the optimization and/or prioritization methods have already been reviewed by the authors (TorresMachí et al., 2014a).

In order to fulfill the described objectives, the study revised first the types of analyses, indicators and models used for the economic and environmental evaluation in the pavement network management; and second, it analyzed the advantages and limitations of the current state of the practice, identifying the improvement opportunities in the sustainable management of these networks.

\section{Analyses and indicators for the economic and environmental evaluation of pavements}

\section{Economic Evaluation}

Pavement economic evaluation can be performed by means of the following types of analyses (FHWA, 2003).

- Life-Cycle Cost Analysis (LCCA): Compares different investment alternatives based on their cost flows over the life-cycle.

- Cost-Benefit Analysis (CBA): Identifies the net benefit of an investment by comparing its present and future costs and benefits. The CBA considers that the selection of a project is justified if the value of the benefits exceeds that of the costs.

- Cost-Effectiveness Analysis (CEA): Considers the costs with their present value and evaluates the benefits through an indicator measuring the investment's effectiveness. Thus, the CEA allows comparing alternatives which generate responses that are difficult to monetize.

- Economic Impact Analysis (EIA): Evaluates the effects on the local, regional or domestic economy by quantifying, among others, the effect on the economic activity, employment, immigration, tourism, etc.

- Financial Analysis (FA): Studies the financing needs of the project over its service life, considering the mismatch between expenditures and available resources.

Table 1. Types of economic analyses and applicable indicators. Source: Self Elaboration, 2013.

\begin{tabular}{|c|c|c|c|c|c|}
\hline \multirow{2}{*}{ Indicator } & \multicolumn{5}{|c|}{ Type of Economic Analysis } \\
\hline & LCCA & CBA & CEA & EIA & FA \\
\hline Net Present Value & $x$ & $x$ & $x$ & $x$ & $x$ \\
\hline Equivalent Annual Cost & $x$ & $x$ & & $x$ & $x$ \\
\hline Internal Rate of Return & & $x$ & & & $x$ \\
\hline Cost-Benefit Ratio & & $x$ & & & \\
\hline Cost-Effectiveness Ratio & & & $x$ & & \\
\hline Investment Return Period & & $x$ & & & $x$ \\
\hline
\end{tabular}

Where, LCCA is Life-Cycle Cost Analysis; CBA is Cost-Benefit-Analysis; CEA is Cost-Effectiveness Analysis; EIA is Economic Impact Analysis; FA is Financial Analysis.

The economic evaluation of the different investment alternatives can be made through a series of indicators presented in Table 1, depending on the type of economic analysis and the aspects considered in it.

Net Present Value (NPV)

The NPV updates the benefits and costs over the analysis period through the discount rate. If it considers the costs only, it is denominated net present value in terms of the cost. The main advantage of the NPV is that the costs and benefits are expressed by a single value, although it requires for the benefits to be monetized. Another advantage is its popularity, since it is the most widespread indicator when assessing projects with public investment (Haas et al., 1994).

\section{Equivalent Annual Cost (EAC)}

This method combines all initial and future capital costs and expresses them as a constant annual cost over the analysis period. It is a simple, easy to understand indicator, which is 
especially useful for annual budgets (Walls \& Smith, 1998). Monetization is necessary if it includes benefits.

Internal Rate of Return (IRR):

The internal rate of return determines the discount rate that equals a project's costs and benefits. The most profitable alternative is that with the highest IRR. This indicator helps evaluating the return of private investments (Walls \& Smith, 1998). However, as it is expressed as a percentage, it does not quantify the total investment amounts; therefore, it generally includes other indicators such as the NPV. Moreover, the method does not consider the benefits that are not monetized.

\section{Cost-Benefit Ratio (CBR)}

CBR represents the ratio between the difference of benefits and present costs; the alternatives with a value higher than the unit are considered profitable. CBR is one of the most widespread methods for project economic evaluation (Browne \& Ryan, 2011). Its main advantage, and also its limitation, is that it monetizes the assessed benefits. However, like the IRR, the CBR does not provide information about the total amounts of costs or benefits.

\section{Cost-Effectiveness Ratio (CER)}

This indicator represents the ratio between the effectiveness of an alternative and its present costs. It evaluates how a specific alternative improves the infrastructure condition and delays the deterioration process (Khurshid et al., 2009). Although different condition indexes can be used for pavement management (Osorio et al., 2014; Chamorro et al., 2010; Chamorro et al., 2009; Chamorro \& Tighe, 2009), the purpose of this indicator is to evaluate if the infrastructure fulfills the needs for which it was built (Uddin et al., 2013).

Pavement deterioration models, expressed by their performance curve, show the evolution of the condition index and the effect of the maintenance activities over time (Chamorro \& Tighe, 2011; Haas et al., 2006; Vera et al., 2010). The performance curve assesses the effectiveness of an alternative by measuring the area bounded by the performance curve and a minimum performance indicator (ABPC) (Fig 2), weighted by factors such as traffic or section length (Eq. 1). Where, $A B P C=$ Area bounded by the performace curve and $a$ threshold value of minimum performance indicator (PImin) (Fig 2). $L=$ Section length. AADT = Annual average daily traffic.

$$
\text { Efectivenness }=A B P C \cdot L \cdot A A D T
$$

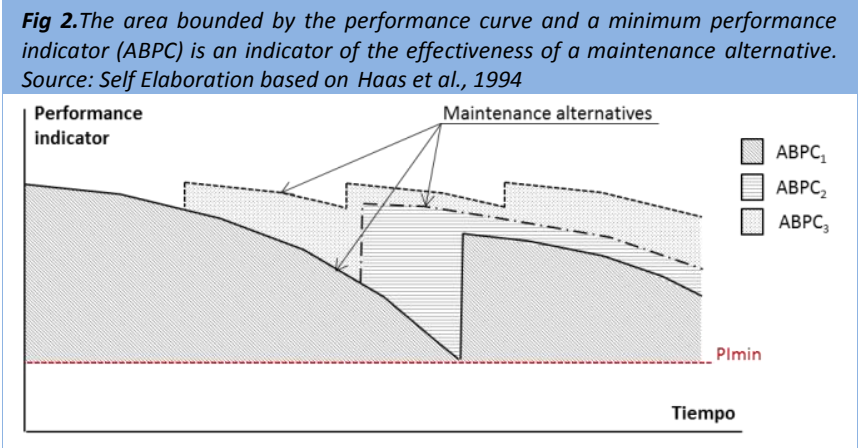

$A B P C$ is a good indicator, since proper maintenance increases its value, thus generating greater benefits for the user. The authors have used this indicator to optimize the problem of allocating resources at the network level (Torres-Machi et al., $2013,2014 b)$. Its main advantage is that it allows including benefits that are difficult to monetize, such as accident reduction, travel time and vehicle operating costs, among others (Khurshid et al., 2009; Chamorro, 2012).

\section{Investment Return Period (IRP)}

This indicator evaluates the time needed to recover a project's capital investment, that is, when the updated benefits equal or exceed the updated costs (Hall et al., 2003). The IRP has similar advantages and limitations as the IRR. It is generally used when assessing the rate of return of private investments and it usually complements other indicators like the NPV.

\section{Environmental Evaluation}

The environmental evaluation for pavement management can be analyzed with the help of ISO 14040 standards "Environmental Management" (ISO, 2006) or sustainability certification systems.

\section{Analysis based on ISO 14040 standards}

Life-cycle assessment (LCA) is a methodology that evaluates a product's environmental impact, from the purchase of raw materials to the production, use, final treatment, recycling, until its final disposal. The indicators used in the evaluations based on the ISO 14040 collect data from emissions and consumption of materials and energy (for example, water consumption, $\mathrm{CO}_{2}$ emissions or $\mathrm{NO}_{\mathrm{x}}$ emissions). This evaluation is applied by models such as PaLATE, Changer and ROAD-RES, among others, which are reviewed in the following section.

\section{Environmental Certification Systems}

These systems are based on the environmental certification of buildings, specifically on the LEED certification system (Leadership in Energy and Environmental Design), created by the U.S. Green Building Council in 1998. The building projects are rated according to different levels covering issues such as energy efficiency, use of alternative energies, improvement of indoor environmental quality, and others (Owensby-Conte \& Yepes, 2012; Ramírez \& Serpell, 2012). Concerning pavements, the indicator is a point-based rating system associated to a certification level similar to the one used in LEED (certified, silver, gold or platinum).

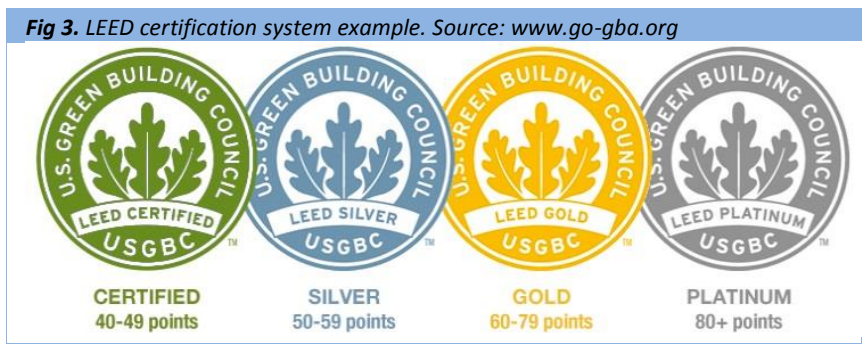


Models for the Economic and Environmental Evaluation of Pavements

\section{Models for Economic Evaluation}

Models that evaluate pavements in economic terms can be classified according to the costs and/or benefits, the indicator and the type of analysis considered. First, this section presents a description of the used costs and benefits and, second, the indicators and the analysis used in the models.

Costs and Benefits in the Economic Evaluation

The costs and benefits considered in the economic evaluation of pavements are classified in the following groups:

- $\quad$ Agency costs: Includes the costs that are necessary to put the infrastructure into service, as well as those associated to maintenance activities and mitigation.

- $\quad$ Effect on users: These effects are calculated by integrating three concepts: accidents, travel time (TT) and vehicle operating costs (VOC), the latter associated to fuel consumption, and wear of tires and other vehicle parts. A distinction is made between the effects generated during normal operation and those derived from work zones. The first correspond to the effects on users during periods when there are no operations that reduce the infrastructure's capacity. The second ones refer to the costs generated when circulating through a section where circulation has been modified due to maintenance or construction operations.

- Externalities: It refers to an action's direct impact on nonusers (FHWA, 2003). They include effects such as air pollution, noises, adverse effects on the water quality, etc. The assessment of these externalities is difficult to monetize (FHWA, 2003; Khurshid et al., 2009). Although there are studies aimed at improving the quantification of these effects (Browne \& Ryan, 2011; Cross et al., 2011), the usual practice is to exclude them from the economic evaluation, and to consider them in the decision making process through additional indicators.

From the above analysis it can be concluded that the concepts to be included in the economic evaluation depend on the type of analysis (Table 2). Thus, for example, the effect on users during normal operation is considered in the cost-benefit analysis (CBA) and in the cost-effectiveness analysis (CEA), but it is not included in the LCCA, because here the alternatives have similar service levels.

Models for the Economic Evaluation of Pavement Preservation Activities

A number of existing economic evaluation models are described:

- The HDM-4 (Highway Development and Management) is a system for pavement management in interurban roads, which allows the economic evaluation of maintenance, construction of new roads and improvement of existing roads, among others (Odoki \& Kerali, 2006).

- $\quad$ The HERS-ST model (Highway Economic Requirements System-State Version), developed by the Federal Highway Administration, evaluates the improvements resulting from rehabilitation and reconstruction operations, excluding preservation treatments (FHWA, 2002).

- $\quad$ The MicroPaver management system, proposed by the US Defense Department for pavement preservation, uses the cost-effectiveness analysis with the $\mathrm{PCl}$ index (Pavement Condition Index) as condition indicator (Colorado State University, 2013).

- The Pavement View Plus system (Cartegraph, 2013) bases the economic evaluation on a cost-effectiveness analysis considering the $\mathrm{OCl}$ condition indicator (Overall Condition Index).

- The RealCost model, developed in the USA by the Federal Highway Administration, is based on the procedure taken from Walls and Smith (1998), which calculates the effect on users during normal operation and in work zones. However, the model is conceived only to evaluate pavement design alternatives, since it does not include preservation tasks.

- The MicroBENCOST model evaluates the users' cost and benefits, embracing seven types of projects: capacity increase, bypass construction, intersection improvements, pavement rehabilitation, bridge improvements, safety improvements, and improvements in railway crossings (Mcfarland et al., 1993). Therefore, it does not assess preservation operations.

In view of these facts, Table 3 was elaborated to compare the analyses and concepts considered in current economic evaluation models. The table shows that all models include benefit evaluation in their economic analyses, although there is no consensus in the type of analysis employed. As for the economic costs and benefits, it shows that several models do not include user costs (VOC, TT and accidents) nor externalities.

\begin{tabular}{|c|c|c|c|}
\hline & LCCA & CBA & CEA \\
\hline \multicolumn{4}{|l|}{ Agency costs } \\
\hline Design \& Engineering & $\checkmark$ & $\checkmark$ & $\checkmark$ \\
\hline Land Purchase & $\checkmark$ & $\checkmark$ & $\checkmark$ \\
\hline Construction & $\checkmark$ & $\checkmark$ & $\checkmark$ \\
\hline Reconstruction \& Rehabilitation & $\checkmark$ & $\checkmark$ & $\checkmark$ \\
\hline Preservation & $\checkmark$ & $\checkmark$ & $\checkmark$ \\
\hline Mitigation & & $\checkmark$ & $\checkmark$ \\
\hline \multicolumn{4}{|l|}{ Effect on users in work zones } \\
\hline Accidents & $\checkmark$ & $\checkmark$ & $\checkmark$ \\
\hline Travel Time ( $\left.\mathrm{TT}_{\text {work zones }}\right)$ & $\checkmark$ & $\checkmark$ & $\checkmark$ \\
\hline Vehicle Operating Cost $\left(\mathrm{VOC}_{\text {work zones }}\right)$ & $\checkmark$ & $\checkmark$ & $\checkmark$ \\
\hline \multicolumn{4}{|l|}{ Effect on users during normal operation } \\
\hline Accidents & & $\checkmark$ & $\checkmark$ \\
\hline Travel Time ( $\left.\mathrm{TT}_{\text {normal }}\right)$ & & $\checkmark$ & $\checkmark$ \\
\hline Vehicle Operating Cost ( $\left.\mathrm{COV}_{\text {normal }}\right)$ & & $\checkmark$ & $\checkmark$ \\
\hline \multicolumn{4}{|l|}{ Externalities (non- users) } \\
\hline Emissions & & $\checkmark$ & $\checkmark$ \\
\hline Noises & & $\checkmark$ & $\checkmark$ \\
\hline Other Impacts & & $\checkmark$ & $\checkmark$ \\
\hline
\end{tabular}

The RealCost model is the only one that includes the effect on users in work zones. Nevertheless, this model has been designed to evaluate pavement project alternatives and, therefore, it is not adequate for network-level management. The same limitation is observed in the models specifically 
developed to evaluate the work zone effect, such as QUEWZ-98 or CA4PRS (Construction Analysis of Pavement Rehabilitation Strategies) (Mallela \& Sadasivam, 2011).

\begin{tabular}{|c|c|c|c|c|c|c|c|}
\hline \multirow{2}{*}{$\begin{array}{l}\text { Economic } \\
\text { Evaluation } \\
\text { Model }\end{array}$} & \multicolumn{2}{|c|}{ Analysis } & \multicolumn{5}{|c|}{ Costs \& Benefits Considered } \\
\hline & $\mathrm{ACB}$ & ACE & Agency & $\begin{array}{l}\text { TT y } \\
\text { COV }\end{array}$ & Acc. & WZ & Ext \\
\hline$H D M-4$ & $\checkmark$ & $\checkmark$ & $\checkmark$ & $\checkmark$ & $\checkmark$ & & $\checkmark$ \\
\hline HERS-ST & $\checkmark$ & $\checkmark$ & $\checkmark$ & $\checkmark$ & $\checkmark$ & & $\checkmark$ \\
\hline MicroPaver & & $\checkmark$ & $\checkmark$ & & & & \\
\hline $\begin{array}{l}\text { Pavement } \\
\text { View Plus }\end{array}$ & & $\checkmark$ & $\checkmark$ & & & & \\
\hline RealCost & $\checkmark$ & & $\checkmark$ & $\checkmark$ & & $\checkmark$ & \\
\hline Microbencost & $\checkmark$ & & $\checkmark$ & $\checkmark$ & $\checkmark$ & & \\
\hline
\end{tabular}

Where, TT is Travel Time; VOC is Vehicle Operating Cost; Acc. is Accidents; WZ is the effect on users in work zones; Ext. is Externalities.

\section{Models for the Environmental Evaluation}

This section reviews the LCA models based on the ISO 14040 standard, followed by environmental certification models.

\section{LCA models based on the ISO 14040 standard}

- The HDM-4 system evaluates the emissions, noise and energy balance. Only the energy balance assessment considers the construction, maintenance and rehabilitation stages, in addition to vehicle circulation. The energy evaluation does not detail each process, but uses aggregate data and thus assigns each treatment an average energy consumption by unit of used material (Bennett \& Greenwood, 2004).

- The PaLATE model (Pavement Life-Cycle Assessment Tool for Environmental and Economic Effects) was developed in 2003 by the University of California, Berkeley, to assess pavement projects in economic and environmental terms. This model evaluates the environmental impact of materials and processes used in a project, considering the design, construction and maintenance stages (Nathman, 2008; Nathman et al., 2009).

- The Changer model (Calculator for Harmonized Assessment and Normalization of Greenhouse-gas Emissions for Roads) was created by the International Road Federation (IRF) to calculate carbon dioxide equivalent emissions caused by pavement construction and maintenance activities (Huang et al., 2013).

- The British model for asphalt pavement assessment, proposed by the Newcastle University, considers the construction and maintenance stage and includes the work zone effect (Huang et al., 2009a; Huang et al., 2009b).

- The ROAD-RES model, proposed by the Technical University of Denmark, is focused on the use of incineration residues, and allows comparing solutions that use virgin and recycled materials (Birgisdóttir, 2005).

- The Caltrans B/C model was developed by the California Department of Transportation for a cost-benefit assessment that would include environmental effects (Booz-Allen \& Hamilton Inc., 1999). Emissions are calculated based on speed and traffic volume and the cost is estimated according to a study developed by Delucchi (1997).
Environmental Certification Models

The main environmental certification models applied to pavement projects are described.

- The CEEQUAL model "Civil Engineering Environmental Quality Assessment and Award Scheme" was developed by the UK Institution of Civil Engineers to assess projects (Willetts et al., 2010) considering aspects such as the use of materials, energy and coal consumption, waste management, etc. A total of 2000 points are distributed among the 12 aspects considered.

- The GreenRoads model, proposed by the University of Washington and Ch2M Hill (Muench et al., 2010, is a certification system based on environmental credits which are applied to new and maintenance highway projects. It considers, among others, the use of materials and resources, environment and water, access and equity, and pavement technologies.

- The GreenLITES model "Green Leadership in Transportation Environmental Sustainability", of the New York State Department of Transportation, is used in the certification of highway design, operation and maintenance projects (NYSDOT, 2013). Its principles are based on GreenRoads' certification and LEED buildings' certification and considers criteria such as the use of recycled materials, use of sustainable products in the machinery, and renovation of shoulders for the safety of pedestrians and cyclists.

- The GreenPave model, developed by the Ministry of Transportation of Ontario (Canada) to evaluate concrete and asphalt pavements, is based on LEED, GreenRoads and GreenLITES certification systems, adapted to the practices used in Ontario (MTO, 2010; Chan et al., 2012). The aim is to strengthen the design and selection of sustainable maintenance alternatives by assessing pavement design technologies, materials and resources, energy and atmosphere, and innovation and design process.

- The BE2ST-in-Highways model "Building Environmentally and Economically Sustainable TransportationInfrastructure-Highways" has been developed by the University of Wisconsin (Madison) and the Recycling Materials Resource Center (RMRC, 2013). It includes nine categories: energy use, global warming potential, recycling in situ, total recycling, water consumption, life-cycle costs, traffic noise and residues. The main novelty is that it uses quantitative tools to evaluate each category, PaLATE for the environmental assessment and RealCost for the economic evaluation.

\section{Discussion}

This section analyses the advantages and limitations of the economic and environmental evaluation of pavements.

\section{Economic Evaluation}

When reviewing the state of the practice, the study shows that economic models take into account the cost-benefit or costeffectiveness analyses in all cases (Table 3). The LCCA is usually not applied, because it is limited to the study of alternatives with similar benefits (and consequently, levels of service). Moreover, the financial and economic impact analyses have different objectives than those mentioned above, and therefore, they are generally developed in a parallel and independent way. In relation to the models used, the cost- 
benefit analysis has the limitation of monetizing certain aspects like the social costs. This limitation is not present in the CEA, since it compares the benefits of different alternatives without an economic assessment; however, it requires an objective methodology to define the benefit-condition ratio through, for example, performance models.

In relation to the economic evaluation models, limitations are detected in the consideration of the effects on users. Traditionally, administrations do not evaluate these effects due to the uncertainty associated to calculation and the penalty represented by these costs, which do not impact the budgets directly (FHWA, 2003). Nevertheless, these costs can have more relevance than the administration costs (Delwar \& Papagiannakis, 2001; Labi \& Sinha, 2003), and so they should be included in the evaluation. Concerning the effects during normal circulation, the complexity of its economic quantification can be avoided through the cost-effectiveness analysis. Furthermore, only the RealCost model includes the effects in work zones in its evaluations (Table 3). However, this method is intended to assess project alternatives; therefore, it does not allow evaluating preservation alternatives and requires data with a high level of detail, and as a result, an evaluation at network level is not viable. Thus, the need to develop a model that evaluates the effect on users in work zones in a network-level management is detected. The execution time of the different preservation options could be used as an indicator, since faster execution alternatives will generate less effect on users.

\section{Environmental Evaluation}

Three key factors are detected when assessing the suitability of an environmental evaluation model:

- Data availability and reliability: this factor is especially relevant in the assessments based on LCA, because these methods require more information, and evaluations are performed with a higher level of detail.

- Transparency and clarity of the evaluations: the evaluation method must provide an objective and transparent assessment concerning the environmental impact.

- Concepts or criteria to be included in the evaluation: they have to consider the specific needs of the evaluation place. Thus, for example, there are models with similar evaluation methodologies which include the peculiarities of different localizations (for example, GreenPave from Ontario versus GreenLITE from New York).

If reliable data are available, LCA models provide more precise evaluations than the environmental certification models, whose variations are usually not based on performance indicators (RMRC, 2013). Therefore, certification models tend to be less transparent than those based on the LCA, thus being subject to more subjective evaluations. However, the assessments obtained by means of certification methods are more intuitive than LCA evaluations, thus being more attractive to convey the benefits of sustainable initiatives to less specialized agents. Therefore, the use of certification models is beneficial for a greater dissemination and understanding of the environmental evaluation, but it should be supported with objective indicators obtained from LCA models. Table 4 shows the main advantages and inconveniences of LCA models.

\section{Integrated Economic-Environmental Evaluation}

After reviewing the analyses, indicators and models used in the economic and environmental evaluation concerning pavement management, a lack of models that envisage the economic and environmental aspects integrally was detected. As it was indicated in the introduction, the integrated consideration of both concepts over the life-cycle is essential to guarantee its sustainable management. In fact, only two of the models revised (HDM-4 and PaLATE) incorporate economicenvironmental analyses in the evaluation of alternatives. However, the HDM-4 does not include the use of recycled materials and new technologies in its environmental evaluation. On the other hand, the PaLATE does not include the effect on users in the economic evaluation.

In view of this situation, it is deemed necessary to develop a model that allows considering the economic and environmental aspects integrally in the allocation of available resources aimed at pavement management and which considers the effect on users both during normal operation and in work zones.

\begin{tabular}{|c|c|c|}
\hline Model & Advantages & Limitations \\
\hline HDM-4 & $\begin{array}{l}\text { Evaluates impact } \\
\text { with aggregate } \\
\text { data. }\end{array}$ & $\begin{array}{l}\text { It evaluates only the energy } \\
\text { consumption of preservation } \\
\text { activities. } \\
\text { It does not allow to consider the } \\
\text { use of recycled materials or new } \\
\text { technologies. }\end{array}$ \\
\hline PaLATE & $\begin{array}{l}\text { Open data and } \\
\text { calculation } \\
\text { Considers } \\
\text { recycled } \\
\text { materials. }\end{array}$ & $\begin{array}{l}\text { Needs data upgrade (obtained in } \\
\text { 1992). }\end{array}$ \\
\hline CHANGER & $\begin{array}{l}\text { Evaluates impact } \\
\text { on carbon } \\
\text { dioxide } \\
\text { equivalent } \\
\text { emissions. }\end{array}$ & $\begin{array}{l}\text { It fails to consider preservation } \\
\text { activities. } \\
\text { It ignores the effect of recycling } \\
\text { tasks. }\end{array}$ \\
\hline $\begin{array}{l}\text { British } \\
\text { Model }\end{array}$ & $\begin{array}{l}\text { Considers use of } \\
\text { recycled } \\
\text { materials. }\end{array}$ & Limited to asphalt pavements. \\
\hline Road-Res & $\begin{array}{l}\text { Considers use of } \\
\text { incineration } \\
\text { residues. }\end{array}$ & $\begin{array}{l}\text { Limited to the use of incineration } \\
\text { residues. }\end{array}$ \\
\hline $\begin{array}{l}\text { Caltrans } \\
\mathrm{B} / \mathrm{C}\end{array}$ & $\begin{array}{l}\text { Economic } \\
\text { assessment of } \\
\text { emissions. }\end{array}$ & $\begin{array}{l}\text { It does not evaluate maintenance } \\
\text { activities. } \\
\text { Monetary evaluation does not } \\
\text { consider current improvements in } \\
\text { reduction of vehicle emissions. }\end{array}$ \\
\hline
\end{tabular}


Following a review of the current models and practices of economic and environmental evaluations for sustainable network-level pavement management, the following conclusions can be drawn as follow:

- Sustainable pavement management requires the integrated consideration of technical, economic, environmental and social aspects over the life-cycle.

- The economic evaluation applied to pavement management needs the assessment of benefits that are difficult to monetize.

- The effects on direct users during normal operation can be evaluated with no need for a monetary quantification from the area below the performance curve. This indicator assesses alternatives considering both technical and economic criteria. The current models of economic evaluation fail to consider the effect on users in work-zones at the network management level, since they require data with a high level of detail which is typical of project-level analyses.

- Two types of analyses are detected for the environmental evaluation of pavements: one based on the ISO 14040 standard and the environmental certification. The first provides a more precise evaluation, but requires a large number of data. The second, more intuitive and easy to assimilate by less specialized agents, is not based on performance indicators, so it can introduce subjective assessments in the evaluation.

- Only two of the reviewed models, HDM-4 and PaLATE, incorporate economic-environmental analyses in the evaluation of alternatives. However, the HDM-4 does not evaluate the use of recycled materials or new technologies, while PaLATE fails to consider the effect on users in the economic evaluation.

The limitations of the models and current state of the practice allow identifying future lines of work:

- In relation to the economic evaluation models, it is necessary to develop a model which considers the effect on users in work zones for a network-level management.

- Regarding the environmental evaluation models, the use of certification models is proposed, which facilitate the dissemination and understanding of the environmental evaluation based on objective indicators obtained from LCA models.

- Finally, the development of models considering economic and environmental criteria integrally is required.

\section{Acknowledgments}

Authors gratefully acknowledge members of the research group at the Pontificia Universidad Católica de Chile for their resources during the study. The research team acknowledges Fondef/Conicyt 2009 for funding the project "Research and Development of Solutions for Urban Pavement Management in Chile" (D09I1018) and the National Research Center for Integrated Natural Disaster Management CONICYT/FONDAP/15110017. Funding over Conicyt (CONICYTPCHA/Doctorado Nacional/2013-63130138) to support this work is sincerely appreciated.
Aldana, J., \& Serpell, A. (2012). Temas y tendencias sobre residuos de construcción y demolición: un meta-análisis. Revista de la Construcción, 11(2), 4-16.

Bennett, C. R., \& Greenwood, I. D. (2004). Modelling road users and environmental effects in HDM-4. Volume 7 of Highway Development and Management Series. Paris: International Study of Highway Development and Management (ISOHDM), World Road Association PIARC.

Birgisdóttir, H. (2005). Life cycle assessment model for road construction and use of residues from waste incineration, PhD Thesis, Technical University of Denmark.

Booz-Allen \& Hamilton Inc. (1999). California Life-Cycle Benefit/Cost Analysis Model (Cal-B/C) (http://www.dot.ca.gov/hq/tpp/offices/eab/benefit_files/tech_supp.pdf) [visited 01.04.13]

Browne, D., \& Ryan, L. (2011). Comparative analysis of evaluation techniques for transport policies. Environmental Impact Assessment Review, 31(3), 226-233.

Cartegraph. (2013). The Operations Management System. (http://www.cartegraph.com). [visited 05.08.13]

Chamorro, A. (2012). Development of a Sustainable Management System for Rural Road Networks in Developing Countries, PhD Thesis, University of Waterloo, Canada.

Chamorro, A., de Solminihac, H., Salgado, M., \& Barrera, E. (2009). Development and Validation of a Method to Evaluate Unpaved Road Condition with Objective Distress Measures. Transportation Research Record, 2101, 3-9.

Chamorro, A., \& Tighe, S. (2009). Development of a Management Framework for Rural Roads in Developing Countries. Transportation Research Record, 2093, 99-107.

Chamorro, A., \& Tighe, S. (2011). Condition performance models for network-level management of unpaved roads. Transportation Research Record, 2204, 21-28.

Chamorro, A., Tighe, S. L., Li, N., \& Kazmierowski, T. J. (2009). Development of distress guidelines and condition rating to improve network management in Ontario, Canada. Transportation Research Record, 2093, 128-135.

Chan, S., Bennett, B., Lane, B., \& Kazmierowski, T. (2012). GreenPave: Ontario's Pavement Sustainability Rating System. TAC Conference and Exhibition, Fredericton, Canada.

Chester, M. V., \& Horvath, A. (2009). Environmental assessment of passenger transportation should include infrastructure and supply chains. Environmental Research Letters, 4(2).

Colorado State University. (2013). PAVER - Pavement Management Software. (http://www.paver.colostate.edu/) [visited 19.08.13]

Cross, S. A., Chesner, W. H., Justus, H. G., \& Kearney, E. R. (2011). LifeCycle Environmental Analysis for Evaluation of Pavement Rehabilitation Options. Transportation Research Record, 2227, 43-52.

Delucchi, M. A. (1997). The Annualized Social Cost of Motor-Vehicle Use in the U.S., 1990-1991: Summary of Theory, Data, Methods, and Results. Davis, California, USA: University of California.

Delwar, M., \& Papagiannakis, A. T. (2001). Relative Importance of User and Agency Costs in Pavement LCCA. Fifth International Conference on Managing Pavements, Washington, USA.

FHWA. (2002). HERS-ST 2.0 Highway Economic Requirements SystemState Version. Washington DC, USA: Federal Highway Administration. 
FHWA. (2003). Economic Analysis Primer. Washington, D.C. USA: Department of Transportation, FHWA, Office of Asset Management.

Haas, R., Tighe, S. L., \& Cowe Falls, L. (2006). Determining return on long-life pavement investments. Transportation Research Record, 1974, 10-17.

Haas, R. C. G., Hudson, W. R., \& Zaniewski, J. P. (1994). Modern Pavement Management. Florida, USA: Krieger Pub Co.

Hall, K., Correa, C., Carpenter, S., \& Elliott, R. (2003). Guidelines for LifeCycle Cost Analysis of Pavement Rehabilitation Strategies. 82st Transportation Research Board Annual Conference. Washington, DC, USA

Huang, Y., Bird, R., \& Bell, M. (2009). A comparative study of the emissions by road maintenance works and the disrupted traffic using life cycle assessment and micro-simulation. Transportation Research Part D: Transport and Environment, 14(3), 197-204.

Huang, Y., Bird, R., \& Heidrich, O. (2009). Development of a life cycle assessment tool for construction and maintenance of asphalt pavements. Journal of Cleaner Production, 17(2), 283-296.

Huang, Yue, Hakim, B., \& Zammataro, S. (2013). Measuring the carbon footprint of road construction using CHANGER. International Journal of Pavement Engineering, 14(6), 590-600.

International Standard Organisation (ISO). (2006). Environmental Management-Life Cycle Assessment: Principles and Framework, Geneva: International Standard Organisation.

IRF (International Road Federation) (2010). IRF World Road Statistics 2010. Geneva: International Road Federation.

Khurshid, M. B., Irfan, M., \& Labi, S. (2009). Comparison of methods for evaluating pavement interventions: Evaluation and case study. Transportation Research Record, 2108, 25-36.

Labi, S., \& Sinha, K. (2003). The effectiveness of maintenance and its impact on capital expenditures. Indiana, USA: Joint Transportation Research Program, Indiana. Department of Transportation and Purdue University, West Lafayette, Indiana.

Mallela, J., \& Sadasivam, S. (2011). Work zone road user costs. Washington, D.C.: Federal Highway Administration.

Mcfarland, W. F., Memmott, J. L., \& Chui, M. K. (1993). Microcumputer evaluation of highway user benefits (No. Project No. 712). Texas, USA: National Cooperative Highway Research Program.

MTO (Ministry of Transportation - Ontario)(2010). GreenPave: Ontario's First Pavement Sustainability Rating System. Road Talk Ontario's Transportation Technology Transfer Digest, 16(1).

Muench, S. T., Anderson, J. L., \& Söderlund, M. (2010). Greenroads: A sustainability performance metric for roadways. Journal of Green Building, 5(2), 114-128.

Nathman, R. (2008). PaLATE user guide, example exercise and contextual discussion. Tesis MSc University of Delaware, USA.

Nathman, R., McNeil, S., \& Van Dam, T. J. (2009). Integrating environmental perspectives into pavement management: Adding the pavement life-cycle assessment tool for environmental and economic effects to the decision-making toolbox. Transportation Research Record, 2093, 40-49.
NYSDOT. (2013). GreenLITES: Recognizing Leadership in Transportation Environmental Sustainability. (https://www.dot.ny.gov/programs/greenlites/) [visited 15.08.13]

Odoki, J. B., \& Kerali, H. R. G. (2006). Analytical Framework and Model Descriptions - Volume 4 of Highway Development and Management Series. Paris: International Study of Highway Development and Management (ISOHDM), World Road Association PIARC.

Osorio, A., Chamorro, A., Tighe, S. L., \& Videla, C. (2013). Calibration and validation of a condition indicator for managing urban pavement networks. Transportation Research Board 93st Annual Meeting, Washington, D.C., USA.

Owensby-Conte, D., \& Yepes, V. (2012). Green Building: Analysis of State of Knowledge. International Journal of Construction Engineering and Management, 1(3), 27-32.

Ramírez, V., \& Serpell, A. (2012). Certificación de la calidad de viviendas en Chile: Análisis comparativo con sistemas internacionales. Revista de la Construcción, 11(1), 134-144.

RMRC. (2013). BE2ST-in-Highways | Recycled Materials Resource Center. (http://rmrc.wisc.edu/be2st-in-highways/) [visited 15.04.13]

SADC. (2003). Low-volume Sealed Roads Guidelines. Gaborone, Botswana: Southern African Development Community.

Solminihac, H. (2001). Gestión de infraestructura vial. Santiago, Chile: Pontificia Universidad Católica De Chile.

Torres-Machi, C., Pellicer, E., Yepes, V., \& Chamorro, A. (2013). Heuristic Optimization Model for Infrastructure Asset Management. In C. Bielza, A. Salmerón, A. Alonso-Betanzos, J. I. Hidalgo, L. Martínez, A. Troncoso, J. M. Corchado (Eds.), Advances in Artificial Intelligence (pp. 300-309). Springer Berlin Heidelberg.

Torres-Machí, C., Chamorro, A., Videla, C., Pellicer, E., \& Yepes, V. (2014a). An iterative approach for the optimization of pavement maintenance management at the network level. The Scientific World Journal, 2014, Article ID 524329. doi:10.1155/2014/524329

Torres-Machí, C., Yepes, V., Pellicer, E., \& Chamorro, A. (2014b). Application of simple and hybrid local search heuristics for the long-term optimization of pavement maintenance strategies at the network level (Vol. 14-2247, pp. 1-11). Transportation Research Board 93st Annual Meeting, Washington, D.C., USA.

Uddin, W., Hudson, R. C. G., \& Haas, R. C. G. (2013). Public infrastructure asset management. New York: McGraw-Hill Education.

Vera, I., Thenoux, G., Solminihac, H. D., \& Echaveguren, T. (2010). Modelo de evaluación técnica del desempeño del mantenimiento de pavimentos flexibles. Revista de la Construcción, 9(2), 76-88.

Walls, J., \& Smith, M. R. (1998). Life-cycle cost analysis in pavement design: in search of better investment decisions. (No. Publication No. FHWA-SA-98-079). Washington, DC, USA: FHWA, U.S. Department of Transportation.

Willetts, R., Burdon, J., Glass, J., \& Frost, M. (2010). Environmental and sustainability impact assessment of infrastructure in the United Kingdom. Transportation Research Record, 2158, 143-150. 